The American Journal of Medical Sciences and Pharmaceutical Research (ISSN - 2689-1026)

VOLUME 04 ISSUE 01 Pages: 1-8

SJIF IMPACT FACTOR (2020: 5. 286) (2021: 5. 64)

OCLC - 1121105510 METADATA IF - 7.569

Crossref dol gु Google

Research Article

\title{
24-HOUR BLOOD PRESSURE MONITORING IN ADOLESCENTS WITH VEGETATIVE DYSTONIA SYNDROME
}

\author{
Submission Date: December 21, 2021, Accepted Date: January 02, 2022, \\ Published Date: January 12, 2022 | \\ Crossref doi: https://doi.org/10.37547/TAJMSPR/Volumeo4Issue01-01 \\ Sh. Kurtieva \\ Researcher, Center for the development of professional qualifications of medical workers, Tashkent, \\ Uzbekistan
}

\section{ABSTRACT}

The aim of this study was to assess the results of 24-hour blood pressure monitoring (ABPM) in adolescents with autonomic dystonia syndrome. We examined 243 adolescents $12-18$ years old with clinically and laboratoryinstrumental confirmed dysfunction of the autonomic nervous system - autonomic dystonia syndrome. It was revealed that in adolescents with autonomic dystonia syndrome, as a result of ABPM, significant deviations from the standards recommended at the moment for assessing the results of ABPM in children were found. The identified deviations may indicate an increase in vascular tone in these children, as well as the presence of disorders associated with the development of cardiovascular complications in adulthood.

\section{KEYWORDS}

Adolescents, autonomic disorders, 24-hour blood pressure monitoring.

\section{INTRODUCTION}

Currently, there is no doubt that its origins lie in childhood and adolescence [1,2,7]. Epidemiological

data indicate that the prevalence of the disease in schoolchildren ranges from 20 to $180 \%$ [3]. The 


\section{The American Journal of Medical Sciences and Pharmaceutical Research}

(ISSN - 2689-1026)

VOLUME 04 ISSUE 01 Pages: 1-8

SJIF IMPACT FACTOR (2020: 5. 286) (2021: 5. 64)

OCLC - 1121105510 METADATA IF - 7.569

\section{Crossref
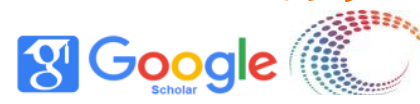 \\ metapenta

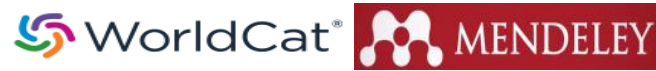

Publisher: The USA Journals

variability of the data can be associated with differences in geographic and ecological characteristics, social status of the subjects, their diet and lifestyle.

In half of the children, the disease is asymptomatic, which makes it difficult to identify, and therefore, its timely treatment. Children with higher than average blood pressure (BP) tend to increase with age. In the future, it remains elevated in $33-42 \%$, and in $17-26 \%$ of children, arterial hypertension progresses, i.e. every third child with elevations in blood pressure may subsequently develop hypertension (4).

For a real change in the existing situation, primary prevention is of the greatest importance, which is based on the concept of risk factors for cardiovascular diseases, confirmed by numerous epidemiological and clinical studies $[5,6]$.

\section{THE MAIN RESULTS AND FINDINGS}

To analyze the results of daily blood pressure monitoring in adolescents with autonomic dystonia syndrome.

243 adolescents of puberty with vegetative dystonia syndrome (SVD) were assessed for 24-hour blood pressure monitoring (ABPM), who were examined in the Teenage Center of the city of Tashkent for the period 2018-2020. Of these, there were 87 adolescent boys, average age $15.0 \pm 2.2$ years, and adolescent girls 156 , average age $15.3 \pm 2.6$ years. In the course of the study, groups of adolescents with SVD were formed depending on gender and a history of perinatal nervous system pathology (PPNS), group 1 consisted of 53 (21.8\%) adolescent boys with PPNS, group 2 - 34 (14.0\% ) adolescent boys without PPNS, 3 groups comprised 107 (44.0\%) adolescent girls with PPNS and group 4 - 49 (20.2\%) adolescent girls without PPNS.
Outpatient ABPM in adolescents was performed using the TM-2421 and TM-2430 monitors from $A \& D$ Company Ltd., using the oscillometric method (in the case of TM-2421, also in combination with the auscultatory method). The study began in the time range from 10 to $12 \mathrm{am}$, carried out according to the standard method. The average number of blood pressure measurements for each adolescent during the day was 46 cases.

The results were processed as follows: calculation of the mean, standard deviation, Mann-Whitney U-test, correlation analysis. Programs used: Microsoft Office Excel, Stadia.

When assessing the mean level of systolic blood pressure (SBP) and diastolic blood pressure (DBP) during wakefulness and nocturnal sleep, the following results were obtained. The mean SBP values in all cases exceeded the levels of the 75th percentile during the waking period and during the night sleep. An excess of the 95th percentile level for SBP was noted in adolescents of both sexes with a history of PPNS.

Average DBP values in adolescents in groups II and IV did not exceed the 75th percentile level during the entire monitoring period. In adolescents of groups I and III, the level of DBP during the day exceeded the value of the 75th percentile, and at night it reached the level of the 95th percentile and even exceeded it.

The presented table 1 shows the ABPM data in adolescents, depending on the magnitude of the pressure load during the day. In the examined adolescents in group I, $28.3 \%$ of cases had a labile form of $\mathrm{AH}(\mathrm{PAH})$, and $5.7 \%$ had stable $\mathrm{AH}(\mathrm{AH})$. In group II, PAH was noted in $11.8 \%$, SAG was found in $2.9 \%$ of cases. In group III, 20.6\% had PAH according to ABPM data and $3.7 \%$ had SAH. As for group IV, PAH was registered in $6.1 \%$ of adolescents, SAG was not recorded. In groups 
The American Journal of Medical Sciences and Pharmaceutical Research (ISSN - 2689-1026)

VOLUME 04 ISSUE 01 Pages: 1-8

SJIF IMPACT FACTOR (2020: 5. 286) (2021: 5. 64)

OCLC - 1121105510 METADATA IF -7.569

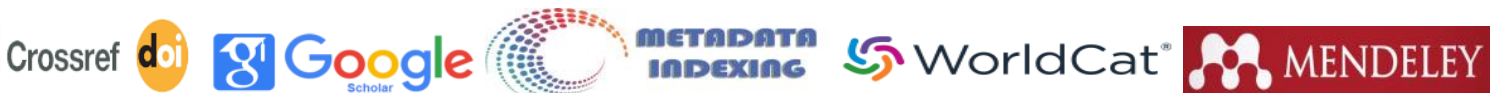

Publisher: The USA Journals

of girls (III and IV), hypotension was significantly more frequent compared to groups of boys (I and II) $23.4 \%$ and $26.5 \%$ versus $7.5 \%$ and $8.8 \%$, respectively. (Table 1 .).

Table 1.

Results of ABPM in adolescents

depending on the availability of PPNS and gender

\begin{tabular}{|c|c|c|c|c|c|c|c|c|c|c|}
\hline \multirow[b]{2}{*}{$\begin{array}{l}\text { Types of } \\
\text { hypertension }\end{array}$} & \multicolumn{4}{|c|}{ Study groups } & \multicolumn{6}{|c|}{ Significance of differences between groups: $p<$} \\
\hline & $\begin{array}{l}\text { Group I, } \\
\mathrm{n}=53\end{array}$ & $\begin{array}{r}\text { Group } \\
\mathrm{II}, \mathrm{n}=34\end{array}$ & $\begin{array}{r}\text { Group } \\
\text { III, } \mathrm{n}=107\end{array}$ & $\begin{array}{c}\text { IV } \\
\text { group, } n=49\end{array}$ & I, II & I, III & I, IV & II, III & II ,IV & ,IV III \\
\hline \multirow[t]{2}{*}{ norm } & 31 & 26 & 56 & 33 & \multirow[b]{2}{*}{$0,05 \%$} & \multirow[b]{2}{*}{$0,001 \%$} & & \multirow[b]{2}{*}{$0,005 \%$} & \multirow[b]{2}{*}{$0,005 \%$} & \multirow[b]{2}{*}{$0,05 \%$} \\
\hline & $58,5 \%$ & $76,5 \%$ & $52,3 \%$ & $67,3 \%$ & & & & & & \\
\hline \multirow{2}{*}{$\begin{array}{l}\text { labile } \\
\text { AG }\end{array}$} & 15 & 4 & 22 & 3 & \multirow[b]{2}{*}{$0,001 \%$} & & \multirow[b]{2}{*}{$0,05 \%$} & \multirow[b]{2}{*}{$0,005 \%$} & & \multirow[b]{2}{*}{$0,05 \%$} \\
\hline & $28,3 \%$ & $11,8 \%$ & $20,6 \%$ & $6,1 \%$ & & & & & & \\
\hline \multirow{2}{*}{$\begin{array}{l}\text { stable } \\
\text { AG }\end{array}$} & 3 & 1 & 4 & 0 & \multirow[b]{2}{*}{$0,05 \%$} & & & \multirow[b]{2}{*}{$0,005 \%$} & & \\
\hline & $5,7 \%$ & $2,9 \%$ & $3,7 \%$ & $0,0 \%$ & & & & & & \\
\hline \multirow[t]{2}{*}{ hypotension } & 4 & 3 & 25 & 13 & \multirow[b]{2}{*}{$0,005 \%$} & \multirow[b]{2}{*}{$0,05 \%$} & \multirow[b]{2}{*}{$0,05 \%$} & & \multirow[b]{2}{*}{$0,005 \%$} & \\
\hline & $7,5 \%$ & $8,8 \%$ & $23,4 \%$ & $26,5 \%$ & & & & & & \\
\hline
\end{tabular}

Thus, BP instability is noted in adolescents with SVD. $\mathrm{PAH}$ is more common in groups of children with a history of PPNS; in the group of adolescent girls, in addition to $\mathrm{PAH}$, a fairly high percentage of children had low BP values compared to the norm.

Subsequently, the data for ABPM were considered in terms of hypertensive load, i.e., depending on the number of measurements of blood pressure, overestimating the established limits, values of the 95th percentile, during the day. In the literature, it is believed that in healthy adolescents this indicator should not exceed $25 \%$, with labile hypertension (PAH), the percentage of excess is from 25 to $50 \%$, and with stable hypertension - $50 \%$ or more in the daytime and at night. Similar approaches to data analysis are also used in pediatrics [Table 2, Fig. 1].

Table 2.

The value of the night decrease in blood pressure (in\%) in the examined adolescents and adolescents

\begin{tabular}{|r|r|r|r|r|}
\hline $\begin{array}{c}\text { Types } \\
\text { of blood } \\
\text { pressure }\end{array}$ & $\begin{array}{l}\text { Group I, } \mathrm{n}= \\
53\end{array}$ & $\begin{array}{c}\text { Group II, } \\
\mathrm{n}=34\end{array}$ & $\begin{array}{c}\text { Group III, } \mathrm{n} \\
=107\end{array}$ & $\begin{array}{c}\text { IV } \\
\text { group, } \mathrm{n}=49\end{array}$ \\
\hline SBP & $12,01+5,7$ & $13,54 \pm 6,8$ & $12,08+5,7^{* *}$ & $13,18+6,3$ \\
\hline DBP & $15,92 \pm 6,8 * \# \wedge$ & $17,16+7,5$ & $16,23 \pm 6,8 * *$ & $17,27+8,1$ \\
\hline
\end{tabular}

Note: * $-\mathrm{p}<0.05$ differences between groups I and II.

$* *$ - $p<0.001$ differences between groups III and IV.

$\wedge$ - $\mathrm{p}<0.001$ differences between groups I and III.

\# - $p<0.001$ differences between groups I and IV. 
The American Journal of Medical Sciences and Pharmaceutical Research (ISSN - 2689-1026)

VOLUME 04 ISSUE 01 Pages: 1-8

SJIF IMPACT FACTOR (2020: 5. 286) (2021: 5. 64)

OCLC - 1121105510 METADATA IF - 7.569

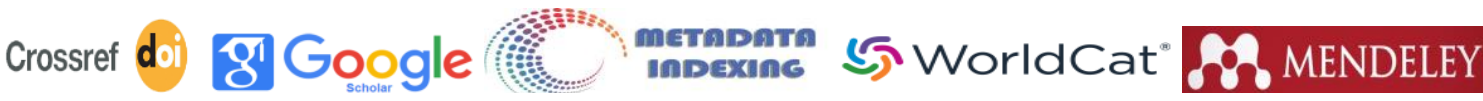

Publisher: The USA Journals

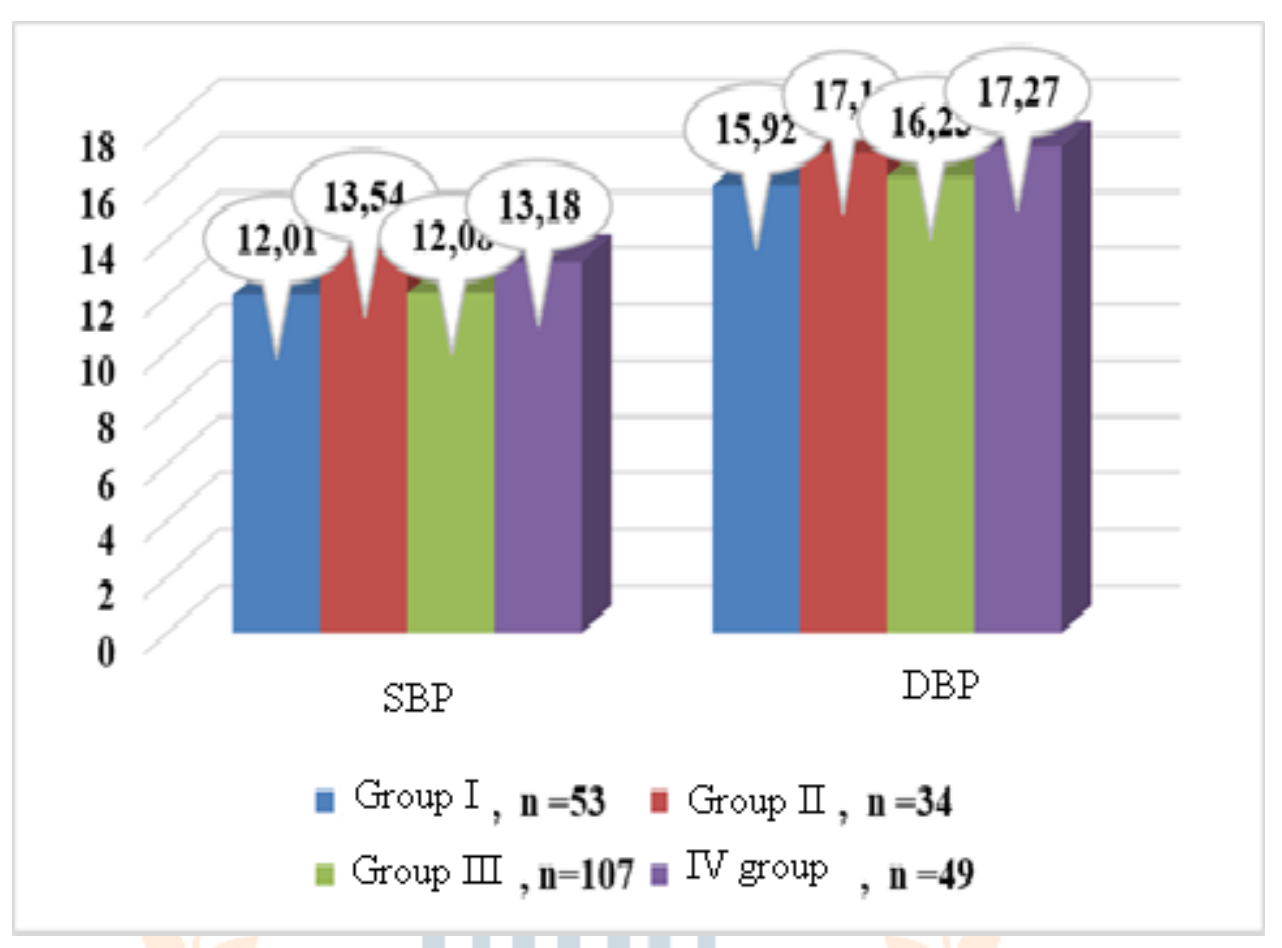

Figure 1. The value of the nighttime decrease in blood pressure (in\%) in the examined adolescents and adolescents.

Table 3 shows the data characterizing the value of the nighttime decrease in blood pressure in the examined adolescents. In groups III and IV, adolescents without PPNS were dominated by patients with an optimal decrease in SBP and DBP at night - dipper (SBP) - 50.0\% and $51.5 \%$, respectively, and dipper (DBP) with insufficient reduction in blood pressure at night - non dipper $-41.5 \%$ and $39.3 \%$, respectively. In the groups of patients with SVD and PPNS, children with insufficient decrease in blood pressure at night prevailed - nondipper (SBP) 37.7\% and 36.4\%, respectively, - non-dipper (DBP) $-24.5 \%$ and $29,0 \%$ respectively. It should be noted that the percentage of cases of insufficient decrease in SBP and DBP in boys was higher than in girls. 
The American Journal of Medical Sciences and Pharmaceutical Research (ISSN - 2689-1026)

VOLUME 04 ISSUE 01 Pages: 1-8

SJIF IMPACT FACTOR (2020: 5. 286) (2021: 5. 64)

OCLC - 1121105510 METADATA IF -7.569

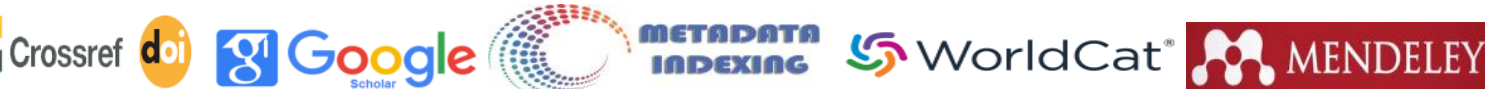

Publisher: The USA Journals

Table 3.

Types of nocturnal BP reduction in adolescents with SVD

\begin{tabular}{|c|c|c|c|c|c|c|c|c|}
\hline \multirow{2}{*}{$\begin{array}{l}\text { Types of } \\
\text { blood pressure } \\
\text { changes } \\
\text { at night }\end{array}$} & \multicolumn{2}{|c|}{ Group I, $n=53$} & \multicolumn{2}{|c|}{ Group II, $\mathrm{n}=34$} & \multicolumn{2}{|c|}{ Group III, $\mathrm{n}=107$} & \multicolumn{2}{|c|}{ IV group, $n=49$} \\
\hline & $\mathrm{n}$ & $\%$ & $\mathrm{n}$ & $\%$ & $\mathrm{n}$ & $\%$ & $\mathrm{n}$ & $\%$ \\
\hline \multicolumn{9}{|l|}{ SBP: } \\
\hline Dipper & 13 & $24,5 \%$ & 17 & $50,0 \%$ & 29 & $27,1 \%$ & 27 & $55,1 \%$ \\
\hline Over-dipper & 14 & $26,4 \%$ & 11 & $32,4 \%$ & 27 & $25,2 \%$ & 15 & $30,6 \%$ \\
\hline Non-dipper & 20 & $37,7 \%$ & 5 & $14,7 \%$ & 39 & $36,4 \%$ & 5 & $10,2 \%$ \\
\hline Night-peaker & 6 & $11,3 \%$ & 1 & $2,9 \%$ & 12 & $11,2 \%$ & 2 & $4,1 \%$ \\
\hline \multicolumn{9}{|l|}{ DBP: } \\
\hline Dipper & 22 & $41,5 \%$ & 18 & $52,9 \%$ & 42 & $39,3 \%$ & 27 & $55,1 \%$ \\
\hline Over-dipper & 12 & $22,6 \%$ & 10 & $29,4 \%$ & 29 & $27,1 \%$ & 17 & $34,7 \%$ \\
\hline Non-dipper & 13 & $24,5 \%$ & 5 & $14,7 \%$ & 31 & $29,0 \%$ & 5 & $10,2 \%$ \\
\hline Night-peaker & 2 & $3,8 \%$ & 1 & $2,9 \%$ & 5 & $4,7 \%$ & 0 & $0,0 \%$ \\
\hline
\end{tabular}

Thus, it can be noted that in groups II and IV, during ABPM (pressure load value less than 25\%), normal indicators of a nighttime decrease in blood pressure were found. At the same time, the degree of nocturnal decrease in DBP in these children and adolescents was insufficient in comparison with the indicators given by M. Soergel. Apparently, this indicates a dysregulation of blood pressure in this group of children with a tendency to increase vascular tone.

In groups I and III of children, the degree of nocturnal decrease in SBP was more pronounced in comparison with the data of $M$. Soergel, although the difference was small. This fact may indirectly indicate a significant proportion in this group with the "daytime" form of labile hypertension. It should be noted that the degree of nocturnal decrease in DBP, as in labile hypertension, was very significantly different from the data of $M$. Soergel in the direction of insufficient decrease.The latter may indicate that in the children we examined with hypertension, significant disturbances in the circadian rhythm of blood pressure were observed, mainly associated with an increase in peripheral vascular resistance.

Noteworthy is the significant proportion of adolescents with over-dipper type nighttime BP reduction and insufficient $B P$ reduction (non-dipper) in children with labile $\mathrm{AH}$. It should be noted that among people with normal blood pressure (according to ABPM data), more often than in the group of confirmed hypertension, there were children who did not give an adequate decrease in blood pressure at night.

In the literature there are indications that in patients with hypertension during outpatient monitoring of blood pressure, an increased variability of blood pressure is recorded $[6,7]$, that increased variability of blood pressure, as well as the degree of nocturnal decrease in blood pressure, has a high prognostic value in terms of the occurrence of cardiovascular complications in adult patients $[2,4]$. 


\section{The American Journal of Medical Sciences and Pharmaceutical Research}

(ISSN - 2689-1026)

VOLUME 04 ISSUE 01 Pages: 1-8

SJIF IMPACT FACTOR (2020: 5. 286) (2021: 5. 64)

OCLC - 1121105510 METADATA IF - 7.569

\section{Crossref dol gil Google}

examined adolescents. The data are presented in Table 4 .

Table 4.

Variability of blood pressure in groups of adolescents with varying degrees of pressure load.

\begin{tabular}{|r|r|r|r|r|}
\hline $\begin{array}{c}\text { BP } \\
\text { variability }\end{array}$ & $\begin{array}{c}\text { Group I, } \mathrm{n} \\
53\end{array}$ & $\begin{array}{c}\text { Group } \\
\mathrm{II}, \mathrm{n}=34\end{array}$ & $\begin{array}{c}\text { Group } \\
\mathrm{III}, \mathrm{n}=107\end{array}$ & $\begin{array}{c}\text { IV group, } \mathrm{n} \\
=49\end{array}$ \\
\hline SBP per day & $12,1 \pm 3,5^{*}$ & $11,6 \pm 3,2$ & $12,3+3,5$ & $11,2 \pm 2,2$ \\
\hline DBP per day & $11,2 \pm 2,8^{*}$ & $9,2 \pm 2,9$ & $10,8+1,5^{\wedge}$ & $8,9 \pm 4,1$ \\
\hline $\begin{array}{c}\text { SBP in the } \\
\text { afternoon }\end{array}$ & $13,2 \pm 3,4^{*}$ & $12,4+4,3$ & $13,6+5,2^{\wedge}$ & $11,9 \pm 2,7$ \\
\hline $\begin{array}{c}\text { DBP in the } \\
\text { afternoon }\end{array}$ & $7,9 \pm 2,6$ & $6,5 \pm 6,1$ & $7,3+5,4$ & $6,7 \pm 1,9$ \\
\hline SBP at night & $10,5 \pm 4,3^{*}$ & $8,4 \pm 2,7$ & $9,6+3,1^{\wedge}$ & $7,9 \pm 2,5$ \\
\hline DBP at night & $8,1 \pm 3,5^{*}$ & $6,3 \pm 2,1$ & $7,8+1,5$ & $6,8 \pm 2,1$ \\
\hline
\end{tabular}

Note * $-p<0.005$ - reliability of differences between groups I and II. ${ }^{\wedge} p<0.005$ - III - IV groups. \# - $p<0.005-$

between groups I and III.

From the above data, it follows that the variability of SBP and DBP in adolescents in groups I and III is significantly greater in comparison with the variability in blood pressure in groups II and IV of adolescents.

The results obtained can be formulated as follows: When studying the circadian rhythm of blood pressure, it was found that the degree of nocturnal decrease in DBP in the examined adolescents with PPNS was significantly less than in adolescents without PPNS examined by M. Soergel. This fact may indicate that an insufficient decrease in vascular tone at night indicates a violation of the pressor and depressor mechanisms in the group of children with PPNS. The study of blood pressure variability showed a significant increase in this indicator depending on the degree of hypertensive load.

Thus, in adolescents with PPNS, as a result of ABPM, significant deviations from the standards recommended at the moment for assessing the results of ABPM in children were found. The identified deviations may indicate an increase in vascular tone in these children, as well as the presence of disorders in them, associated with the development of cardiovascular complications in the adult state. These deviations were noted not only in adolescents with SVD with PPNS, but also in the group of patients with SVD without PPNS. 
The American Journal of Medical Sciences and Pharmaceutical Research (ISSN - 2689-1026)

VOLUME 04 ISSUE 01 Pages: 1-8

SJIF IMPACT FACTOR (2020: 5. 286) (2021: 5. 64)

OCLC - 1121105510 METADATA IF - 7.569

Crossref dol gु' Google

5.

6.

7.

8.

9. dispensary observation of children and adolescents with SVD.

\section{REFERENCES}

1.

2.

3.

4.

Kislyak O.A. Arterial hypertension in adolescence / O.A. Kislyak. - M : Miklos, 2007 .-- 288 p.

Leontyeva I.V. Lectures on pediatric cardiology / I.V. Leontyev. - M : Medpraktika, 2005 - 536 p.

Recommendations for the prevention, diagnosis and treatment of arterial hypertension // Cardiovascular therapy and prevention, 2009. - No. 4, Appendix. - $32 \mathrm{p}$.

Shulutko B.I. Arterial hypertension 2000 / B.I. Shulutko. - SPb .: RENKOR, $2001 .-382$ p.
Zimmet P., Alberti K.G., Kaufman F. et al. IDF Consensus Group. The metabolic syndrome in children and adolescents an IDF consensus report. Pediatr Diabetes, 2007; 8 (5): 299-306.

Jolliffe C.J., Janssen I. Distribution of lipoproteins by age and gender in adolescents. Circulation, 2006; 114: 1056.

WHO. Defi nition and Diagnosis of Diabetes Mellitus and Intermediate Hyperglycemia. Report of a WHO/IDF Consultation. Geneva: World Health Organization, 2006; 1-46.

Куртиева, Ш. (2021). CHANGES IN ELECTROENCEPHALOGRAM

INDICATORS IN ADOLESCENTS WITH VEGETATIVE DYSFUNCTION. УЗБЕКСКИЙ МЕДИЦИНСКИЙ ЖУРНАЛ, (SPECIAL 3).

Куртиева, Ш., Иноятова, Ф. И., \& Гафуров, Б. Г. (2021). ХОЗИРГИ ЗАМОН ЎСМИРЛАРИДА ФУНКЦИОНАЛ КАРДИОПАТИЯ СИНДРОМИНИ САБАБЛАРИ. ЖУРнал теоретической и клинической медицины, (1), 39-42.

Мухамедова, М. Г., Куртиева, Ш. А., \& Назарова, ж. А. (2020). СИНДРОМ ФУНКЦИОНАЛЬНОЙ КАРАИОПАТИИ У СОВРЕМЕННЫХ ПОДРОСТКОВ. In П84 Профилактическая медицина2020: сборник научных трудов Всероссийской научно-практической конференции с международным участи-ем. 18-19 ноября 2020 года/под ред. АВ Мельцера, Иш Якубовой. Ч. 2.-СПб.: Изд-во СЗГМУ 
The American Journal of Medical Sciences and Pharmaceutical Research (ISSN - 2689-1026)

VOLUME 04 ISSUE 01 Pages: 1-8

SJIF IMPACT FACTOR (2020: 5. 286) (2021: 5. 64)

OCLC - 1121105510 METADATA IF -7.569

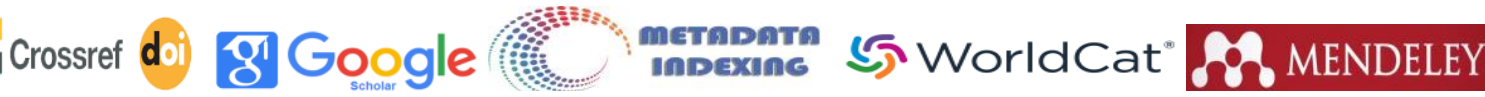

им. ИИ Мечникова, 2020.-304 с. (р.

105).

11. Юлдашева, М. М., Маджидова, Ё. Н., Гафуров, Б. Г., Назарова, Ж. А., Доронина, О. Б., \& Доронин, Б. М. (2019). Особенности церебральной венозной гемодинамики при острых нарушениях мозгового кровообращения. Практическая медицина, 17(7).

12. Гафуров, Б. Г., Аликулова, Н. А., \& Назарова, ж. А. (2019). Роль церебральной венозной дисгемии в формировании хронической недостаточности мозгового кровообращения. Фундаментальные In инновационного развития науки и образования (рр. 223-241).

13. Аликулова, Н. А., Назарова, Ж. А., \& Рахматова, С. Н. (2018). Гендерные различия когнитивных функций при цереброваскулярной патологии. World science, $1(10$ (38)).

14. Назарова, Ж. А., \& Бахадирханов, М.

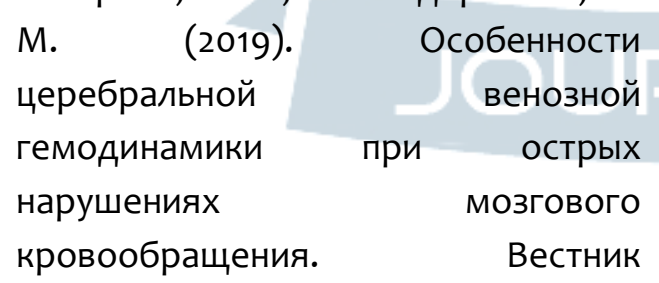
экстренной медицины, 12(6).

15. Назарова, Ж. А. (2019). Оценка клинического и нейрофизиологического состояния когнитивных функций при венозной церебральной дисфункции. Справочник врача общей практики, (1), 33-39. 